\title{
ВІРТУАЛЬНА ВИСТАВКА «БОРИС ПАТОН I УКРАЇНСЬКА ГУМАНІТАРИСТИКА»
}

\author{
https://doi.org/10.37472/2707-305X-2021-3-1-18-1
}

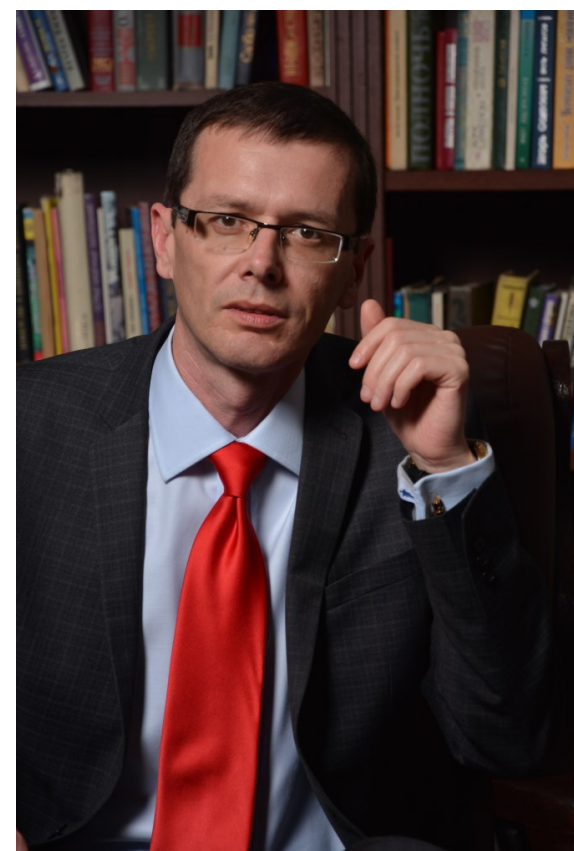

МІХНО Олександр Петрович кандидат педагогічних наук, старший науковий співробітник, директор Педагогічного музею України, м. Київ, Україна

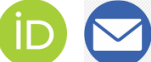

Анотація. Віртуальна виставка «Борис Патон і українська гуманітаристика» підготовлена Педагогічним музеєм України для вшанування пам'яті видатного українського вченого Бориса Патона (1918-2020) з ініціативи президента НАПН України Василя Кременя. Автор виставки - Олександр Міхно, директор Педагогічного музею України. Виставка складається з семи розділів: "Батьківська педагогіка», "Освіта. Вчителі. Наставники», "Б. Патон - президент Національної академії наук України», "Б. Патон - голова Комітету з Державних премій України в галузі науки і техніки», "НАН України і НАПН України», «Б. Патон про майбутне соціогуманітарних наук», "In Memoriam». В оформленні виставки використано висловлювання Бориса Патона про науку, наставництво, сутність людського щастя, а також 19 фотографій. Структурним елементом виставки $\epsilon$ відео, яке в стислій формі передає зміст виставки та ії візуальний ряд. Відеоформат виставки зроблено з метою ії представлення в Үоитиве, зокрема для віртуальних відвідувачів із тяжкими порушеннями зору в межах роботи музею в напрямі інклюзії. Література, використана для створення виставки, доступна для завантаження у PDF-форматі. Виставка розміщена на офіщійному сайті Педагогічного музею України.

Ключові слова: Борис Патон; віртуальна виставка; українська гуманітаристика; структура виставки; НАН України; НАПН України; Педагогічний музей України.

7 квітня 2021 р. на засіданні Президії Національної академії педагогічних наук України відбулася презентація віртуальної виставки «Борис Патон і українська гуманітаристика», яка підготовлена Педагогічним музеєм України НАПН України для вшанування пам'яті видатного українського вченого Бориса Патона (19182020).

Структурно виставка складається з семи розділів, які в хронологічній послідовності висвітлюють окремі аспекти життєвого і творчого шляху Бориса Євгеновича Патона, розкривають процес формування його гуманістичного світогляду:

- «Батьківська педагогіка»;

- «Освіта. Вчителі. Наставники»;

- «Б. Патон - президент Національної академії наук України»;

- «Б. Патон - голова Комітету з Державних премій України в галузі науки і техніки»;

- «НАН України і НАПН України»;

- «Б. Патон про майбутнє соціогуманітарних наук»;

- «In Memoriam».

У розділі «НАН України і НАПН України» подано інформацію про створення у 1994 р. з ініціативи Національної академії наук (НАН) України Ради президентів академій наук України. Головою Ради було обрано Бориса Патона. Рада $€$ органом сприяння розвитку всього сектору академічної науки в поєднанні з освітянською наукою (Кремень, 2012, с. 414). 


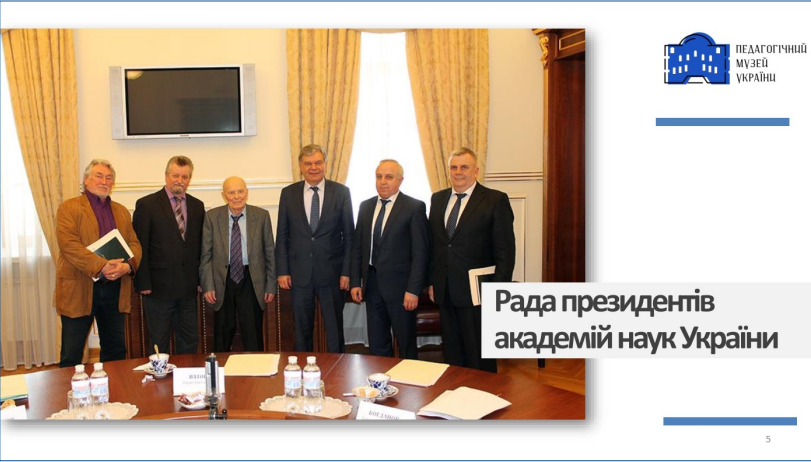

Також у розділі йдеться про те, що плідна багаторічна співпраця НАН України і $\mathrm{HAПH}$ України зумовлена зокрема і особистісним людським чинником. Ця теза розкривається через висловлювання Бориса Патона і Василя Кременя.

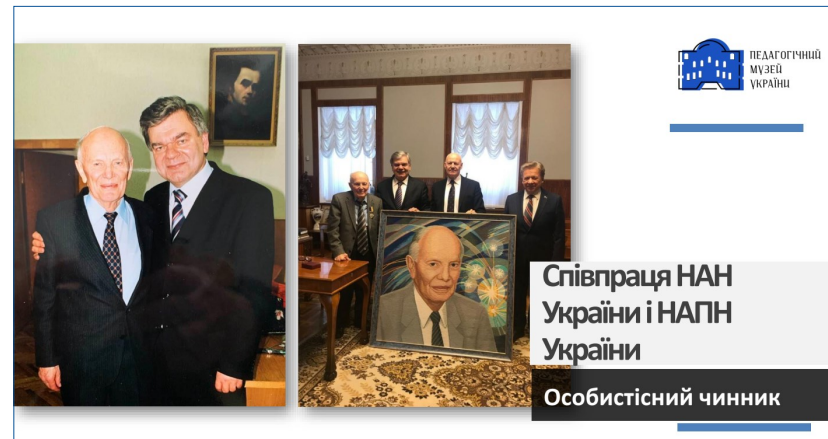

Так, в інтерв'ю газеті «Освіта України» Василь Кремень відзначив, що саме Борис Патон став ініціатором його призначення Міністром освіти і науки України у грудні 1999 р.: «Я був першим Міністром, за якого освіта і наука об'єдналися. Я не планував ним стати. Але так трапилося, що
Прем'єр-міністр Віктор Ющенко перед тим, як призначати Міністра, зібрав актив і радився. Запросили і мене - тоді голову підкомітету Комітету Верховної Ради України з питань науки і освіти. I Віктор Андрійович звертається до Бориса Патона: «Ось ми створюємо спільне Міністерство освіти і науки. Будь ласка, скажіть, кого ви бачите на посаді Міністра?» Борис Євгенович каже: «я можу не тільки сказати, а й показати. Це Кремень» (Кремень, 2017).

Віртуальна виставка містить і такий прийом, як пряма мова: подано фото президента НАПН Василя Кременя і його цитату: "Борис Євгенович Патон - це Людина з великої літери, Людинапланета. Дуже ціную добре ставлення Бориса Євгеновича до мене. Саме за його пропозицією я був призначений двадцять років тому першим Міністром об'єднаного Міністерства освіти і науки України. Усі п'ять років я відчував його підтримку, а сам намагався всіляко сприяти Національній академії наук України та іншим науковим структурам у їх важливій діяльності. Національна академія педагогічних наук України і товариство «Знання» України, які я маю честь очолювати, щиро вдячні Борису Євгеновичу за підтримку їх діяльності».

У розділі також представлено Програму спільної діяльності НАН України та НАПН України на 2020-2022 роки, підписану 6 квітня 2020 р. Борисом Патоном і Василем Кременем.

Щодо особливостей оформлення виставки, зокрема ілюстративного матеріалу, який супрово-

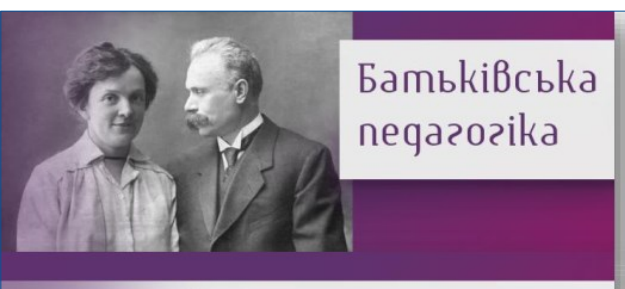

0cBima. Вчumeni. HacmaBhuku.

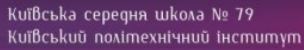

Б. Патон - презияент Національної akaqемії наук Vkраїнu

Б. Патон - голова Коміmemу з Аержаßних премій үkраїнu $\mathrm{B}$ галузі науku i mexнiku

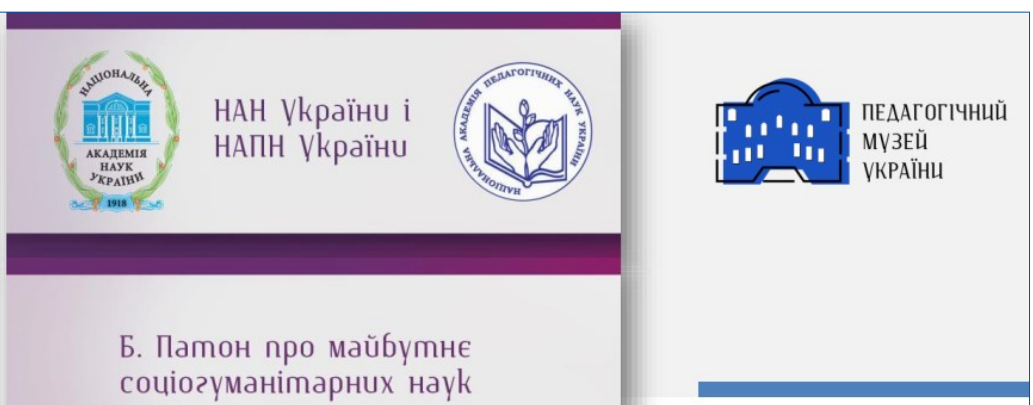

Структура

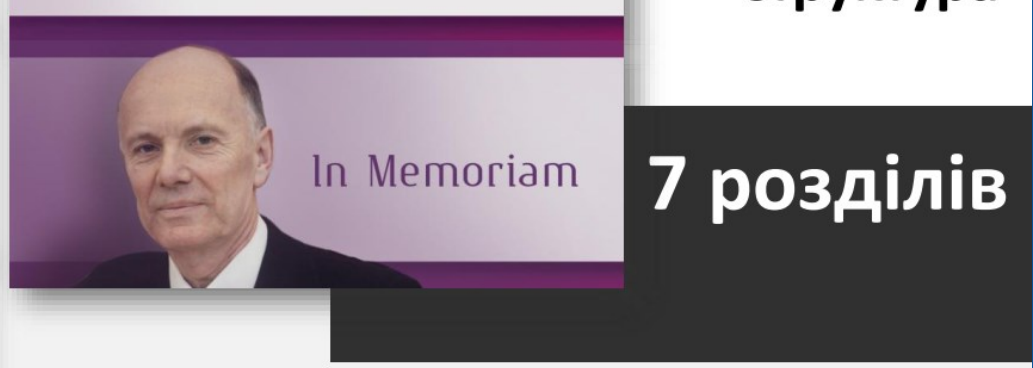




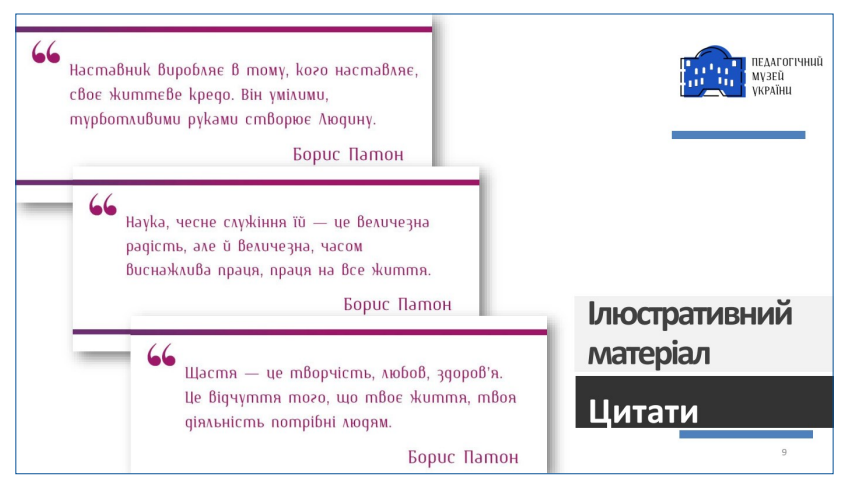

джує текстову інформацію, то важливим $є$ використання цитат Бориса Патона про науку, наставництво, сутність людського щастя. Звісно, віртуальна виставка містить унікальні світлини, які ретельно відібрані, аби не переобтяжувати виставку візуальним матеріалом. Це, наприклад, раритетне фото Євгена Оскаровича Патона 3 фондів Педагогічного музею України, рідкісні фото Бориса Патона - студента Київського політехнічного інституту та фото диплома лауреата Державної премії УРСР Василя Сухомлинського за книгу «Серце віддаю дітям». Цю нагороду видатному педагогу присуджено у 1974 р. (посмертно). Диплом підписано Борисом Патоном - головою Комітету із Державних премій УРСР у галузі науки і техніки. Загалом на виставці представлено 19 неповторних фотографій.

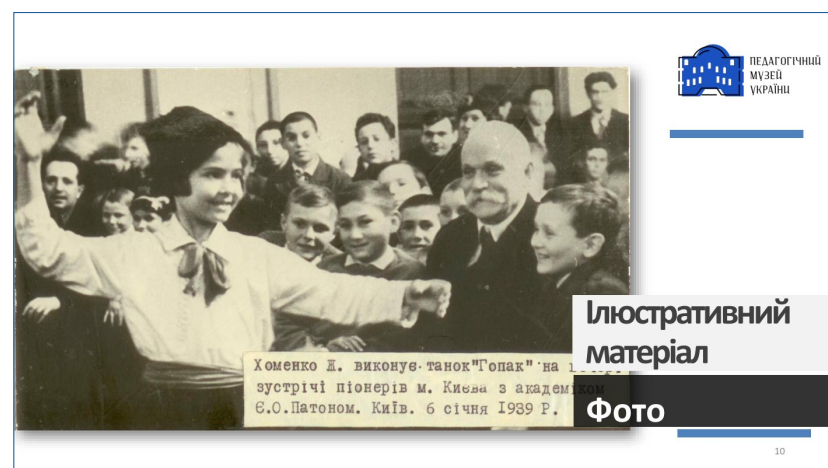

Одним із вагомих структурних елементів виставки є відео, яке в стислій формі відтворює текст і візуальний ряд виставки. Відеоформат зроблено для представлення виставки в YouTube, зокрема для віртуальних відвідувачів із тяжкими порушеннями зору в межах роботи музею в напрямі інклюзії.

Представлені джерела та література, використані для створення виставки, - це теж ії структурні елементи. Джерела подано в PDF-форматі та активними посиланнями, тож зацікавлений відвідувач має змогу дізнатися більше інформації і щодо теми виставки, і загалом про життя та діяльність Бориса Патона. Зокрема, багато

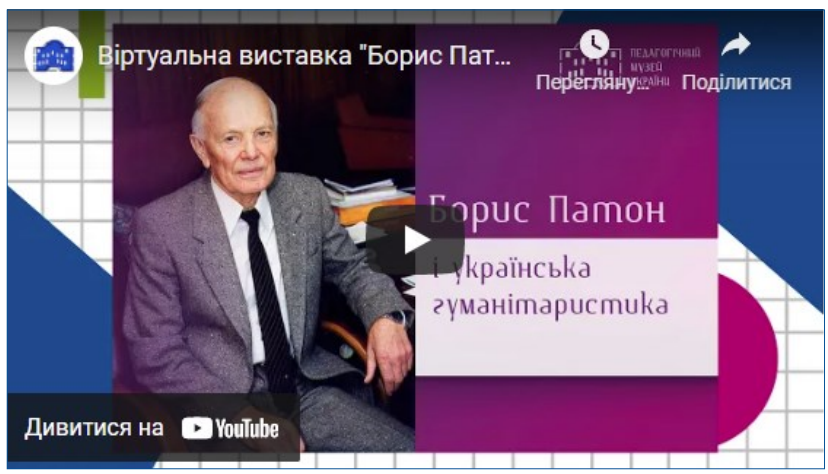

цікавих фактів про видатного вченого містить книга Б. Малиновського «Академік Борис Патон - праця на все життя» (2002), яку можна вільно завантажити за розміщеним у списку літератури покликанням.

Завершує виставку розділ «Подяки». І це не випадково, адже рушієм будь-якої справи є ідея. Ідея вшанування пам'яті Бориса Патона в НАПН України належить ії̈ президенту - акад. Василю Кременю. Автор виставки - директор Педагогічного музею України Олександр Міхно висловлює вдячність акад. Світлані Сисоєвій, академікусекретарю Відділення загальної педагогіки і філософії освіти НАПН України - за підтримку і допомогу, акад. Ользі Сухомлинській, головному науковому співробітнику Державної науковопедагогічної бібліотеки України ім. В.О. Сухомлинського НАПН України - за консультацію і надані фотоматеріали, колегам - співробітникам Педагогічного музею України Ларисі Гайді, Валентині Єфімовій, Андрію Онищуку, Віктору Гайдею - за знайдені й підготовлені для опрацювання чудові матеріали та креативні ідеї щодо їх представлення широкій аудиторії, Олексію Воробйову - за ретельно створений відеоформат.

Зміст виставки відображено у статті «Борис Патон і українська гуманітаристика», опублікованій у газеті Міністерства освіти і науки України «Освіта України» (№ 13 від 5 квітня 2021 р.). Матеріали цієї виставки використовуватимуться у діяльності Науково-інформаційного центру НАПН України (кер. - Світлана Сисоєва).

3 виставкою можна ознайомитися на офіційному сайті Педагогічного музею України. На офіційному сайті НАПН України розміщено інформацію про виставку. Відеоформат виставки доступний для перегляду також на YouTubeканалі Педагогічного музею України.

\section{СПИСОК ВИКОРИСТАНИХ ДЖЕРЕЛ}

Кремень, В.Г. (2012). Б.Є. Патон і галузеві академії наук України. In Б.Є. Патон: 50 років на чолі Академії (с. 412-421). Київ: Академперіодика. http://irbisnbuv.gov.ua/ulib/item/0001618 
Кремень, В. (2017, 26 червня). Український учитель відкритий до творчості. Освіта України, (25). http:// naps.gov.ua/ua/press/about_us/1200/

Малиновський, Б.М. (2002). Академік Борис Патон праця на все життя. Київ: Наукова думка.

Міхно, О. (2021, 5 квітня). Борис Патон і українська гуманітаристика. Освіта України, (13).

Національна академія педагогічних наук України. (2021, 6 квітня). Віртуальна виставка «Борис Патон і українська гуманітаристика». http:// naps.gov.ua/ua/press/exhibitions/2272/
Національна академія педагогічних наук України (2020). Програма спільної діяльності Національної академії наук України та Начіональної академії педагогічних наук України на 2020-2022 роки. http://naps.gov.ua/ua/activities/research/nas/

Педагогічний музей України. (2021). Борис Патон $i$ українська гуманітаристика. Віртуальна виставка. http://pmu.in.ua/actual-info/borys_paton/

Педагогічний Музей. (2021, 2 березня). Віртуальна виставка "Борис Патон і українська гуманітаристика» [Відео]. YouTube. https://youtu.be/iini5s-PcOI

\title{
VIRTUAL EXHIBITION "BORYS PATON AND THE UKRAINIAN HUMANITIES"
}

\author{
Oleksandr Mikhno \\ PhD in Pedagogy, Senior Researcher, Director, Pedagogical Museum of Ukraine, Kyiv, Ukraine
}

\begin{abstract}
The virtual exhibition "Borys Paton and the Ukrainian Humanities" was prepared by the Pedagogical Museum of Ukraine to honor the memory of the outstanding Ukrainian scientist Borys Paton (1918-2020) on the initiative of Vasyl Kremen, President of the National Academy of Educational Sciences of Ukraine. The author of the exhibition is Oleksandr Mikhno, Director of the Pedagogical Museum of Ukraine. The exhibition consists of seven sections: "Parental pedagogy", "Education. Teachers. Mentors", "B. Paton - President of the National Academy of Sciences of Ukraine", "B. Paton - Chairman of the Committee on State Prizes of Ukraine in the field of science and technology", "National Academy of Sciences of Ukraine and National Academy of Educational Sciences of Ukraine", "B. Paton on the future of the social sciences and humanities", "In Memoriam". B. Paton's statements about science, mentoring, the essence of human happiness, as well as 19 photographs were used in the design of the exhibition. The structural element of the exhibition is a video, which in a concise form conveys the content of the exhibition and its visual range. The video format of the exhibition was made for the purpose of its presentation on YouTube, as well as within the work of the museum in the direction of inclusion, in particular for virtual visitors with severe visual impairments. The literature used to create the exhibition is available for download in PDF format. The exhibition is posted on the official website of the Pedagogical Museum of Ukraine.

Keywords: Borys Paton; virtual exhibition; Ukrainian humanities; exhibition structure; National Academy of Sciences of Ukraine; National Academy of Educational Sciences of Ukraine; Pedagogical Museum of Ukraine.
\end{abstract}

Дата публікації: 10 квітня 2021 р. 